\title{
Microwave plasma for hydrogen production from liquids
}

Dariusz Czylkowski, Bartosz Hrycak, Robert Miotk, Mariusz Jasiński, Jerzy Mizeraczyk, Mirosław Dors

\begin{abstract}
The hydrogen production by conversion of liquid compounds containing hydrogen was investigated experimentally. The waveguide-supplied metal cylinder-based microwave plasma source (MPS) operated at frequency of $915 \mathrm{MHz}$ at atmospheric pressure was used. The decomposition of ethanol, isopropanol and kerosene was performed employing plasma dry reforming process. The liquid was introduced into the plasma in the form of vapour. The amount of vapour ranged from 0.4 to $2.4 \mathrm{~kg} / \mathrm{h}$. Carbon dioxide with the flow rate ranged from 1200 to $2700 \mathrm{NL} / \mathrm{h}$ was used as a working gas. The absorbed microwave power was up to $6 \mathrm{~kW}$. The effect of absorbed microwave power, liquid composition, liquid flow rate and working gas flow rate was analysed. All these parameters have a clear influence on the hydrogen production efficiency, which was described with such parameters as the hydrogen production rate $\left[\mathrm{NL}\left(\mathrm{H}_{2}\right) / \mathrm{h}\right]$ and the energy yield of hydrogen production $\left[\mathrm{NL}\left(\mathrm{H}_{2}\right) / \mathrm{kWh}\right.$. The best achieved experimental results showed that the hydrogen production rate was up to $1116 \mathrm{NL}\left(\mathrm{H}_{2}\right) / \mathrm{h}$ and the energy yield was $223 \mathrm{NL}\left(\mathrm{H}_{2}\right)$ per $\mathrm{kWh}$ of absorbed microwave energy. The results were obtained in the case of isopropanol dry reforming. The presented catalyst-free microwave plasma method can be adapted for hydrogen production not only from ethanol, isopropanol and kerosene, but also from different other liquid compounds containing hydrogen, like gasoline, heavy oils and biofuels.
\end{abstract}

Key words: dry reforming $\bullet$ ethanol $\bullet$ hydrogen production $\bullet$ isopropanol $\bullet$ kerosene $\bullet$ microwave plasma

D. Czylkowski ${ }^{\bowtie}$, B. Hrycak, R. Miotk, M. Jasiński, M. Dors

The Szewalski Institute of Fluid-Flow Machinery of the Polish Academy of Sciences,

14 Fiszera Str., 80-231 Gdańsk, Poland,

Tel.: +4858699 5214, Fax: +4858 3416144 ,

E-mail: dczylkowski@imp.gda.pl

\section{J. Mizeraczyk}

Department of Marine Electronics,

Gdynia Maritime University,

81-87 Morska Str., 81-225 Gdynia, Poland

Received: 25 September 2015

Accepted: 20 November 2015

\section{Introduction}

Currently, worldwide there is high interest in the hydrogen production and storage technology. It is the point of interest to both the scientific and research units, as well as companies looking for innovative and future-oriented technologies. This is evident as a number of international conferences are devoted to this subject (e.g. World Hydrogen Technologies Convention, held in October 2015 in Australia or Euro-Mediterranean Hydrogen Technologies Conference, held in December 2014 in Italy). There are many different factors determining the possibility of commercial implementing systems for hydrogen production like lower operation and production costs and improved efficiency.

In accordance with the growing interest in the hydrogen production technologies, in this study, we propose an atmospheric pressure microwave plasma source (MPS) for hydrogen production via conversion of liquid compounds containing hydrogen. Microwave plasma has many advantages. The parameters (temperature of the gas, the electron density) can be adjusted over a wide range. Microwave atmospheric plasmas exhibit very high electron densities. A large number of inelastic electron-neutral collisions result in very efficient 
dissociation at relatively high concentrations. Such inelastic collisions proceed permanently, with the consequence of also preventing the reformation of the initial molecules. As a result, high pollutant destruction and removal efficiencies may be attained even at high concentrations [1]. The microwave plasma sources at atmospheric pressure stand out from the other plasma sources as being more efficient in energy transfer [2]. Properly designed microwave plasma generators provide nearly one hundred percent energy transfer from the electromagnetic field of microwaves into the plasma. Moreover, the costs of microwave discharge production are low due to the fact that for its generation standard commercial magnetron and microwave components could be used. Discharge at atmospheric pressure does not require the use of expensive vacuum pumps. Due to its specific features, fields of plasma application are very wide: from biomedicine (sterilization, deactivation of bacteria and viruses on living tissues) via UV and VUV radiation as well as visible light sources and in gas processing to typical technical application (treatment and modification of various surfaces) [3-12].

In this paper, we present results of the experimental investigations on the hydrogen production by conversion of liquid compounds containing hydrogen. The waveguide-supplied metal cylinder-based MPS [13] operating at frequency of $915 \mathrm{MHz}$ at atmospheric pressure was used. The decomposition of ethanol, isopropanol and kerosene as liquid compounds containing hydrogen was performed employing plasma dry reforming process which was catalyst-free.

\section{Experimental set-up}

Different designs of microwave plasma generators operated at atmospheric pressure have been developed. The sketch of the MPS used in our experimental study is presented in Fig. 1. This waveguide-supplied metal cylinder-based MPS [13] was based on a standard WR 975 rectangular waveguide with inside a section of reduced-height followed by tapered section. In such a type of the MPS, the plasma is generated inside a dielectric discharge tube made of quartz. This tube with the inner and outer diameters of 26 and $30 \mathrm{~mm}$, respectively, penetrated the waveguide through circular gaps on the centre line of the waveguide wide wall. A working gas was introduced into the plasma region by four inlets, which form a swirl flow inside the quartz cylinder. The gas swirl stabilizes the plasma and also protects the quartz cylinder wall from the heat. This made possible the operation at the microwave power level of a few $\mathrm{kW}$. The quartz tube was enveloped by an outer cylindrical metal electrode, with a longitudinal slot, which is a part of the waveguiding structure of the MPS. It also protected the personnel and electronic equipment against the microwave leakage from the discharge tube. The longitudinal slot (not shown in Fig. 1) in the outer cylindrical electrode made the optical observations possible. There was also

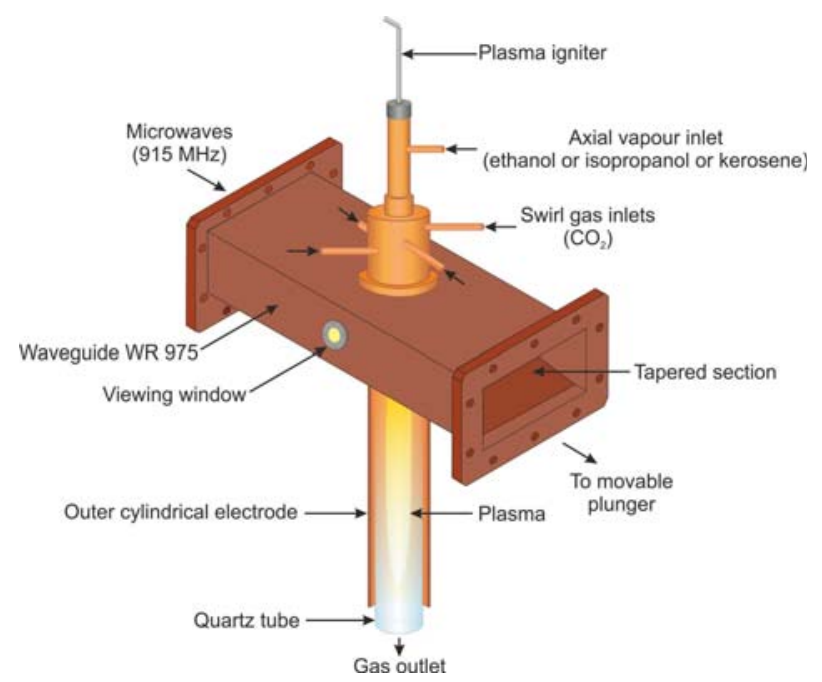

Fig. 1. Sketch of the waveguide-supplied metal cylinder-based MPS.

viewing window, enabling plasma observation, in the waveguide interior region. A metal igniter was used for making the microwave breakdown and initiating the plasma generation. It was experimentally proved that similar MPS operated at frequency of $2.45 \mathrm{GHz}$ is a high potential tool for hydrogen production via methane conversion $[14,15]$. Recently, it was used for hydrogen production from different liquids like ethanol and isopropanol [16-18].

All the reported experiments were carried out using a set-up described in detail below. Figure 2 shows its essential parts, where a $915 \mathrm{MHz}$ microwave power generator with adjustable power was used. The microwave generator, in one case, consisted of a magnetron head and a high voltage supply with a microwave generator control unit. The microwave power was fed via a circulator, bi-directional coupler and three-stub tuner to the MPS. The circulator protected the generator against possible damages caused by the reflected microwave power. The calibrated directional coupler with two power meter heads and a digital dual-channel microwave power meter was used to monitor the incident and reflected microwave power levels. There were two impedance matching components. The three-stub tuner mentioned above was mounted before the MPS while a movable plunger was placed at the end of the MPS. A three-stub tuner and movable plunger made it possible to achieve the reflected microwave power level at the MPS input of negligible value. This helped in maximizing the efficiency of the microwave energy transfer to the microwave plasma.

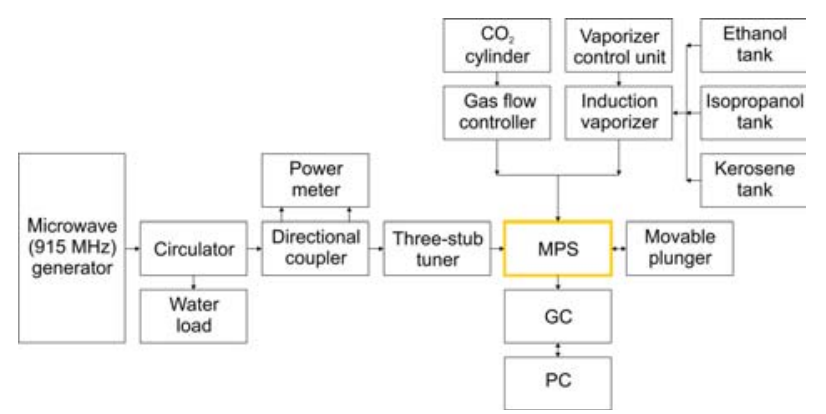

Fig. 2. Schematic diagram of the experimental set-up. 


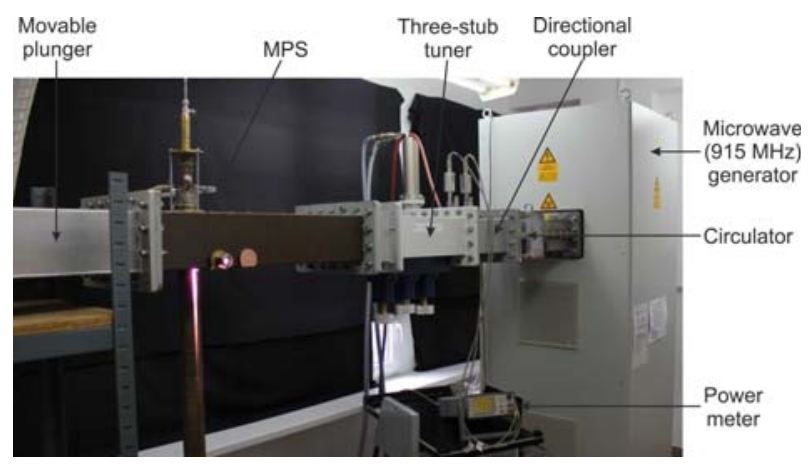

Fig. 3. Photo of the experimental set-up.

The working gas (carbon dioxide) flow rate was controlled by a mass flow controller (MFC) placed before the MPS gas inlet. An inductively heated vaporizer with temperature and flow rate control was used to produce ethanol, isopropanol and kerosene vapours. The inlet and outlet gas compositions were determined using SRI 8010C and Shimadzu 2014 Gas Chromatographs (GC). A photo of the experimental set-up is shown in Fig. 3.

As it was stated above, in our experiment, the liquid was introduced into the plasma in the form of a vapour. The amount of vapour ranged from 0.4 to $2.4 \mathrm{~kg} / \mathrm{h}$. Carbon dioxide with the flow rate ranging from 1200 to $2700 \mathrm{NL} / \mathrm{h}$ was used as a working gas. The absorbed microwave power of frequency of $915 \mathrm{MHz}$ was up to $6 \mathrm{~kW}$. The MPS was operated at atmospheric pressure.

\section{Results}

In this experimental study, the dry reforming of ethanol, isopropanol and kerosene was studied experimentally. Operating parameters were: absorbed microwave power, working gas flow rate, liquid compounds containing hydrogen and the liquid flow rate. The efficiency of hydrogen production was described by hydrogen production rate in $\left[\mathrm{NL}\left(\mathrm{H}_{2}\right) / \mathrm{h}\right]$, and the energy yield of hydrogen production in $\left[\mathrm{NL}\left(\mathrm{H}_{2}\right) /\right.$ $\mathrm{kWh}]$, which were calculated from mass balance of conversion products.

The results of the hydrogen production rate as a function of absorbed microwave power for different liquid compounds containing hydrogen are presented in Fig. 4. Three series of measurements are presented. The first one is for ethanol at flow rate of 0.4 and $0.8 \mathrm{~kg} / \mathrm{h}$. The second one is for isopropanol at a flow rate of 0.4 and $0.8 \mathrm{~kg} / \mathrm{h}$ and the third one is for kerosene at a flow rate of 0.4 and $0.8 \mathrm{~kg} / \mathrm{h}$. For each measurement, the $\mathrm{CO}_{2}$ flow rate was fixed at $2700 \mathrm{NL} / \mathrm{h}$. As one may expect, the hydrogen production rate should increase with an increase in the absorbed microwave power. This can be clearly seen in the case of $0.8 \mathrm{~kg} / \mathrm{h}$ liquid flow rate. The growth of the hydrogen production rate with increasing absorbed microwave power could be explained by the plasma column elongation with increasing microwave power delivered to the plasma. As a result of this, the residence time of the reactants in the plasma region increased. That was not the

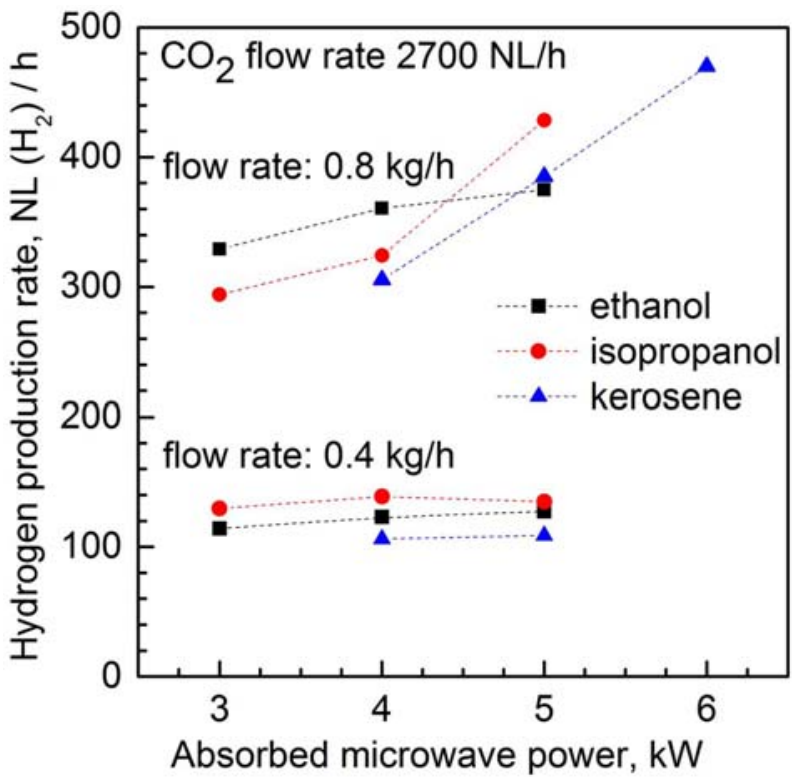

Fig. 4. Hydrogen production rate as a function of absorbed microwave power for three liquid compounds containing hydrogen (ethanol, isopropanol, kerosene) of different flow rates $(0.4$ and $0.8 \mathrm{~kg} / \mathrm{h}) . \mathrm{CO}_{2}$ flow rate was $2700 \mathrm{NL} / \mathrm{h}$.

case for smaller flow rates of liquids $(0.4 \mathrm{~kg} / \mathrm{h})$. In that case, the hydrogen production rate was almost constant with the absorbed microwave power.

In contrast to the case of the hydrogen production rate, the energy yield decreased with an increase in the absorbed microwave power, which is seen in Fig. 5. As in the case of data presented in Fig. 4, results correspond to three liquid compounds containing hydrogen (ethanol, isopropanol, kerosene) of different flow rates $(0.4 \mathrm{~kg} / \mathrm{h}$ and $0.8 \mathrm{~kg} / \mathrm{h})$ and a $\mathrm{CO}_{2}$ flow rate of $2700 \mathrm{NL} / \mathrm{h}$. The energy yield of hydrogen production in $\left[\mathrm{g}\left(\mathrm{H}_{2}\right) / \mathrm{kWh}\right]$ is defined as the ratio of hydrogen mass produced using an energy of $1 \mathrm{kWh}$ (also as the ratio of the hydrogen production rate to absorbed microwave power in

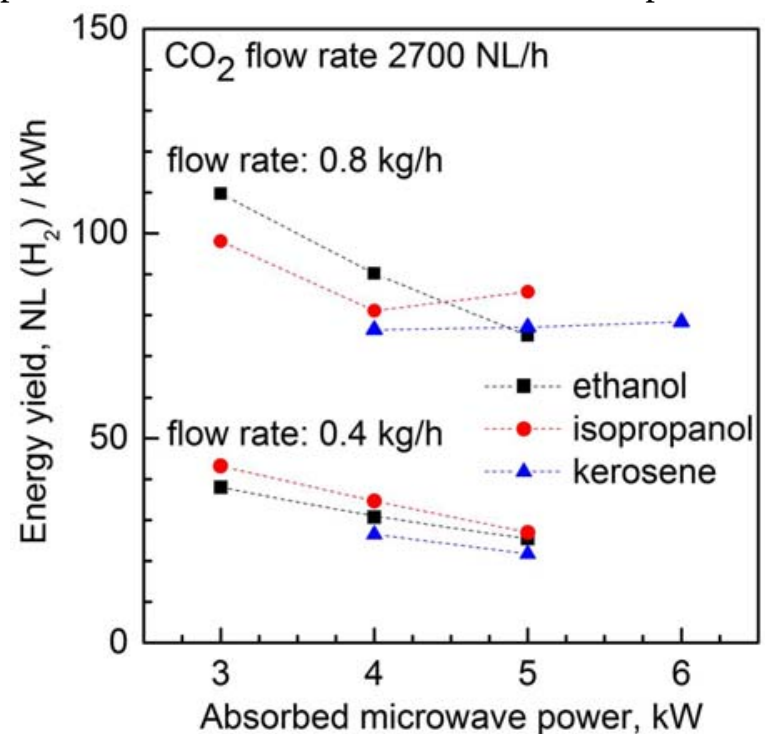

Fig. 5. Energy yield of hydrogen production as a function of absorbed microwave power for three liquid compounds containing hydrogen (ethanol, isopropanol, kerosene) of different flow rates $(0.4$ and $0.8 \mathrm{~kg} / \mathrm{h}) \cdot \mathrm{CO}_{2}$ flow rate was $2700 \mathrm{NL} / \mathrm{h}$. 


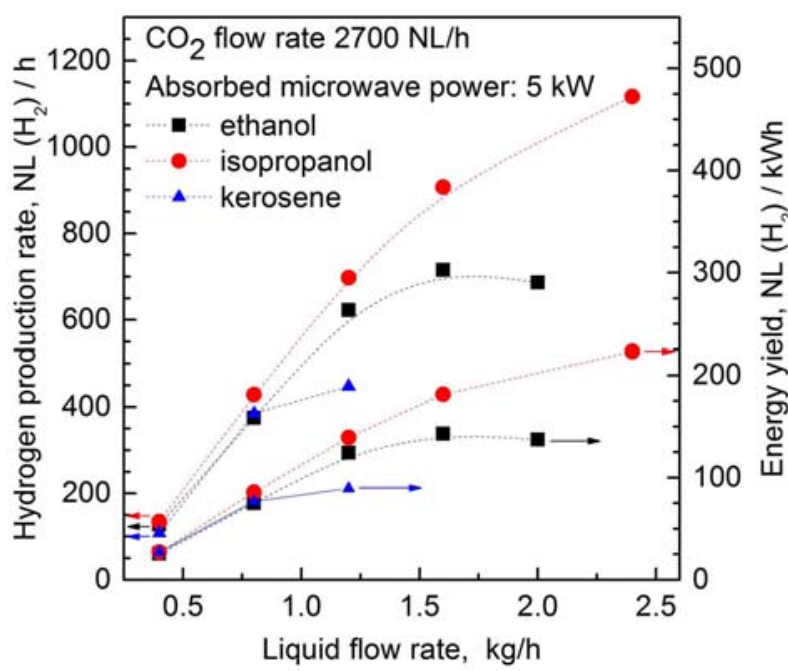

Fig. 6. Hydrogen production rate and energy yield of hydrogen production as a function of liquid compounds containing hydrogen (ethanol, isopropanol, kerosene) flow rate. $\mathrm{CO}_{2}$ flow rate $-2700 \mathrm{NL} / \mathrm{h}$. Absorbed microwave power was $5 \mathrm{~kW}$.

$\mathrm{kW}$ ). Due to the fact that, in our case, the growth of the hydrogen production rate is not proportional to the absorbed microwave power, the energy yield of hydrogen production decreases. In other words, the growth of the absorbed microwave power is faster than the corresponding hydrogen production rate.

Figure 6 displays the results of the hydrogen production rate and the energy yield of hydrogen production as a function of ethanol, isopropanol and kerosene flow rate. The presented results correspond to $\mathrm{CO}_{2}$ flow rate of $2700 \mathrm{NL} / \mathrm{h}$ flow rate. The absorbed microwave power was $5 \mathrm{~kW}$. The results show that increasing the amount of liquid vapour introduced to the plasma resulted in higher values of the tested parameters. However, when using ethanol and kerosene at sufficiently high liquid flow rates, the hydrogen production rate and the energy yield of hydrogen production are saturated. This is not the case with isopropanol where at flow rate up to $2.4 \mathrm{~kg} / \mathrm{h}$ the saturation effect was not observed. In that case, the hydrogen production rate and the energy yield of hydrogen production are highest for the highest applied isopropanol flow rate $(2.4 \mathrm{~kg} / \mathrm{h})$. The best results of the hydrogen production rate and the energy yield were $1116 \mathrm{NL}\left(\mathrm{H}_{2}\right) / \mathrm{h}$ and $223 \mathrm{NL}\left(\mathrm{H}_{2}\right) / \mathrm{kWh}$, respectively.

The results of the gaseous by-products diagnostics, related to the results presented in Fig. 6, are shown in Table 1 . The results concern the dry reforming of ethanol, isopropanol and kerosene carried out at $5 \mathrm{~kW}$ of absorbed microwave power and $2700 \mathrm{NL} / \mathrm{min}$ of $\mathrm{CO}_{2}$ flow rate. As it can be seen hydrogen $\left(\mathrm{H}_{2}\right)$, carbon monoxide $(\mathrm{CO})$, the unprocessed carbon dioxide $\left(\mathrm{CO}_{2}\right)$, methane $\left(\mathrm{CH}_{4}\right)$, acetylene $\left(\mathrm{C}_{2} \mathrm{H}_{2}\right)$, ethylene $\left(\mathrm{C}_{2} \mathrm{H}_{4}\right)$ and ethane $\left(\mathrm{C}_{2} \mathrm{H}_{6}\right)$, were recorded in the outlet gas volume. The conversion degree of the $\mathrm{CO}_{2}$ is estimated to be about 52 , 56 and $43 \%$ in the case of ethanol, isopropanol and kerosene dry reforming, respectively.

The results of the influence of working gas $\left(\mathrm{CO}_{2}\right)$ flow rate on the efficiency parameters of hydrogen
Table 1. Details on the output gas composition in the case of ethanol, isopropanol and kerosene dry reforming. Ethanol, isopropanol and kerosene flow rates were 1.6, 2.4 and $1.2 \mathrm{~kg} / \mathrm{h}$, respectively. $\mathrm{CO}_{2}$ flow rate $-2700 \mathrm{NL} / \mathrm{h}$. Absorbed microwave power $-5 \mathrm{~kW}$

\begin{tabular}{lccc}
\hline $\begin{array}{c}\text { Products } \\
\text { in the outgas } \\
{[\%]}\end{array}$ & $\begin{array}{c}\text { Ethanol } \\
1.6 \mathrm{~kg} / \mathrm{h}\end{array}$ & $\begin{array}{c}\text { Isopropanol } \\
2.4 \mathrm{~kg} / \mathrm{h}\end{array}$ & $\begin{array}{c}\text { Kerosene } \\
1.2 \mathrm{~kg} / \mathrm{h}\end{array}$ \\
\hline $\mathrm{H}_{2}$ & 17.2 & 23.5 & 11.7 \\
$\mathrm{CO}$ & 48.5 & 37.8 & 38.9 \\
$\mathrm{CO}_{2}$ & 30.8 & 25.2 & 40.2 \\
$\mathrm{CH}_{4}$ & 1.2 & 6.4 & 2.0 \\
$\mathrm{C}_{2} \mathrm{H}_{2}$ & 1.3 & 2.7 & 2.6 \\
$\mathrm{C}_{2} \mathrm{H}_{4}$ & 0.2 & 2.1 & 2.1 \\
$\mathrm{C}_{2} \mathrm{H}_{6}$ & 0.05 & 0.14 & 0 \\
\hline
\end{tabular}

production in the case of isopropanol dry reforming are shown in Fig. 7. For this case, the isopropanol vapour flow rate was set to $1.6 \mathrm{~kg} / \mathrm{h}$ and the absorbed microwave power was $5 \mathrm{~kW}$. Similarly, as it was observed for ethanol dry reforming using $2.45 \mathrm{GHz}$ microwave plasma [18], the results show that increasing $\mathrm{CO}_{2}$ flow rate resulted in lower values of the hydrogen production rate and the energy yield of hydrogen production. Both of them are highest for the lowest $\mathrm{CO}_{2}$ flow rate. This can be explained by a dilution effect. As a result of this, the purity of the hydrogen is lower and energy consumption of the process is higher. Also, when increasing the $\mathrm{CO}_{2}$ flow rate the system is far away from the stoichiometric ratio of the isopropanol, ethanol and kerosene dry reforming reaction. It should be mentioned here that $\mathrm{CO}_{2}$ plays also a different role in the experiment. The $\mathrm{CO}_{2}$ swirl concentrated near the quartz tubes wall, in which the plasma is generated, stabilizes plasma generation and protects the quartz tube wall from overheating. Therefore, when operating with microwaves of the order of a few $\mathrm{kW}$, a higher gas flow rate is recommended. Summarizing, the $\mathrm{CO}_{2}$ flow rates were selected for possibility of plasma generation, plasma stability and repeatability.

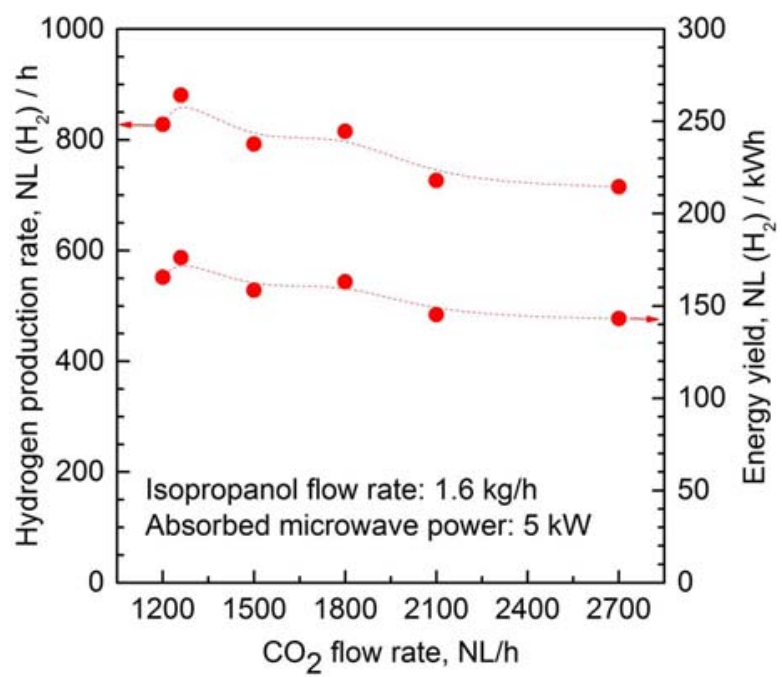

Fig. 7. Hydrogen production rate and energy yield of hydrogen production as a function of $\mathrm{CO}_{2}$ flow rate for dry reforming of isopropanol. Absorbed microwave power was $5 \mathrm{~kW}$. 
Table 2. Comparison of the best achieved the hydrogen production rates and the energy yields of hydrogen production from different liquid compounds containing hydrogen in the case of $\mathrm{CO}_{2}$ flow rate of $2700 \mathrm{NL} / \mathrm{h}$ and absorbed microwave power of $5 \mathrm{~kW}$

\begin{tabular}{lccc}
\hline $\begin{array}{c}\text { Liquid } \\
\text { compound } \\
\text { containing } \\
\text { hydrogen }\end{array}$ & $\begin{array}{c}\text { Liquid } \\
\text { flow rate } \\
{[\mathrm{kg} / \mathrm{h}]}\end{array}$ & $\begin{array}{c}\text { Hydrogen } \\
\text { production rate } \\
{\left[\mathrm{NL}\left(\mathrm{H}_{2}\right) / \mathrm{h}\right]}\end{array}$ & $\begin{array}{c}\text { Energy } \\
\text { yield } \\
{\left[\mathrm{NL}\left(\mathrm{H}_{2}\right) / \mathrm{kWh}\right]}\end{array}$ \\
\hline Ethanol & 1.6 & 715 & 143 \\
Isopropanol & 2.4 & 1116 & 223 \\
Kerosene & 1.2 & 447 & 89 \\
\hline
\end{tabular}

The energetic analysis of the presented hydrogen production method should be made on the basis of the energy yield of hydrogen production [18]. A summary of the best achieved the hydrogen production rates as well as the energy yields of hydrogen production from different liquid compounds containing hydrogen is presented in Table 2 . The results concern processes at $\mathrm{CO}_{2}$ flow rate of $2700 \mathrm{NL} / \mathrm{h}$ and absorbed microwave power of $5 \mathrm{~kW}$. As it can be seen from the table, the best results of the hydrogen production rate and the energy yield of hydrogen production were achieved in the case of isopropanol dry reforming. These were $1116 \mathrm{NL}\left(\mathrm{H}_{2}\right) / \mathrm{h}$ and $223 \mathrm{NL}\left(\mathrm{H}_{2}\right) / \mathrm{kWh}$, respectively (per kWh of microwave energy used). The lowest hydrogen production efficiency parameters were achieved for kerosene dry reforming. In that case, the hydrogen production rate and the energy yield of hydrogen production were up to $447 \mathrm{NL}\left(\mathrm{H}_{2}\right) / \mathrm{h}$ and up to $89 \mathrm{NL}\left(\mathrm{H}_{2}\right) / \mathrm{kWh}$. The energy yield of hydrogen production, as a hydrogen production efficiency parameter, may be indicative for different hydrogen production methods. Based on it, different methods of hydrogen production can be compared from energetic analysis point of view. In the previous papers $[17,18]$, a table with comparison of selected plasma methods of hydrogen production from liquids was added.

The energetic profitability can be also considered taking into account the US Department of Energy's target for the industrial acceptable the energy yield, which should be not less than $60 \mathrm{~g}\left(\mathrm{H}_{2}\right) / \mathrm{kWh}$ in 2020 [19]. During our experimental study, the best obtained result of the energy yield of hydrogen production is about $19 \mathrm{~g}\left(\mathrm{H}_{2}\right) / \mathrm{kWh}$. This could be improved by optimizing the way of introduction the liquid into the plasma. Currently, the works concerning that problem are in progress.

\section{Summary and conclusions}

In this paper, the results of the production of hydrogen via dry reforming of different liquids using the waveguide-supplied metal cylinder-based MPS operating at atmospheric pressure were presented. The MPS enables the processing of ethanol, isopropanol and kerosene at flow rates up to $2.4 \mathrm{~kg} / \mathrm{h}$, with carbon dioxide as a working gas of flow rate ranged from 1200 to $2700 \mathrm{NL} / \mathrm{h}$ and with an absorbed microwave power of several $\mathrm{kW}$. The influence of the absorbed microwave power, liquid compound containing hydrogen, liquid flow rate and carbon dioxide flow rate on the hydrogen production efficiency was investigated. The efficiency of hydrogen production was described by the hydrogen production rate and the energy yield of hydrogen production.

The best achieved experimental results showed that isopropanol dry reforming was more efficient in hydrogen production than ethanol and kerosene dry reforming. In that case, the hydrogen production rate and energy yield of hydrogen production were up to $1116 \mathrm{NL}\left[\mathrm{H}_{2}\right] / \mathrm{h}$ and up to $223 \mathrm{NL}\left[\mathrm{H}_{2}\right]$ per $\mathrm{kWh}$ of microwave energy used, respectively.

It is worth to notice that the presented microwave plasma method for hydrogen production from liquids is catalyst-free. The plasma is a source of highly active species, such as electrons, ions and radicals, which may enhance the reforming reaction rate. High reactivity eliminates the need for expensive and impurity vulnerable catalysts in the system [20-22]. Additionally, since the $\mathrm{CO}_{2}$ conversion is more beneficial to reduce greenhouse gas to produce CO by dry reforming, one should consider presented here method as environment-friendly.

The method of the hydrogen production presented here must overcome a few problems before its commercial application. One of the main problems is hydrogen purity. It should be pointed out that in the proposed hydrogen production method a gas mixture is obtained as a final product. Diagnostics of output gas composition showed that except for hydrogen $\left(\mathrm{H}_{2}\right)$, the rest, carbon dioxide $\left(\mathrm{CO}_{2}\right)$, carbon monoxide $(\mathrm{CO})$, methane $\left(\mathrm{CH}_{4}\right)$, ethane $\left(\mathrm{C}_{2} \mathrm{H}_{6}\right)$, ethylene $\left(\mathrm{C}_{2} \mathrm{H}_{4}\right)$ and acetylene $\left(\mathrm{C}_{2} \mathrm{H}_{2}\right)$ were registered as gaseous by-products. Elimination of carbon dioxide and by-products, which are impurities, is necessary for achieving hydrogen of high quality. The recycled carbon dioxide could be returned back to the plasma for further dry reforming processing. The major existing technologies of hydrogen purification, that is, pressure swing adsorption and selective membrane processes, with their advantages and limitations are discussed in [23]. The proposal of hybrid microwave plasma system for production of hydrogen from hydrocarbons (e.g. methane) was proposed in [14]. The system consists of an atmospheric pressure plasma source, a soot filter, a high pressure compressor and a gas separator unit.

The results of our investigations proved that hydrogen may be produced by the dry reforming of ethanol, isopropanol and kerosene and can be used for hydrogen production from other liquid compounds containing hydrogen, like gasoline, heavy oils and biofuels. The presented microwave plasma based method of hydrogen production from liquids could be one of the solutions for hydrogen production in distributed hydrogen generation systems.

Acknowledgments. We are grateful to the National Science Centre (Programme no. 2012/05/B/ST8/02789) for the financial support of this work.

This work was performed at the Szewalski Institute of Fluid-Flow Machinery of the Polish Academy of Sciences in Gdańsk, Poland. 


\section{References}

1. Kabouzi, Y., Moisan, M., Rostaing, J. C., Trassy, C., Guerin, D., Kéroack, D., \& Zakrzewski, Z. (2003). Abatement of perfluorinated compounds using microwave plasmas at atmospheric pressure. J. Appl. Phys., 93(12), 9483-9496. DOI: 10.1063/1.1574595.

2. Moisan, M., \& Pelletier, J. (1992). Microwave excited plasmas. Amsterdam, Holland: Elsevier.

3. Mizeraczyk, J., Dors, M., Jasiński, M., Hrycak, B., \& Czylkowski, D. (2013). Atmospheric pressure low-power microwave microplasma source for deactivation of microorganisms. Eur. Phys. J. Appl. Phys., 61, 24309. DOI: 10.1051/epjap/2012120405.

4. Czylkowski, D., Hrycak, B., Jasiński, M., Dors, M., \& Mizeraczyk, J. (2013). Atmospheric pressure microwave microplasma microorganisms deactivation. Surf. Coat. Technol., 234, 114-119. DOI: 10.1016/j. surfcoat.2013.04.010.

5. Chen, H. H., Weng, C. C., Liao, J. D., Chen, K. M., \& Hsu, B. W. (2009). Photo-resist stripping process using atmospheric pressure microplasma system. J. Phys. D-Appl. Phys., 42(13), 1-8. DOI: 10.1088/0022-3727/42/13/135201.

6. Denes, F. S., \& Manolache, S. (2004). Macromolecular plasma-chemistry: an emerging field of polymer science. Prog. Polym. Sci., 29(8), 815-885. DOI: 10.1016/ j.progpolymsci.2004.05.001.

7. Chu, P. K., Chen, J. Y., Wang, L. P., \& Huang, N. (2002). Plasma-surface modification of biomaterials. Mater. Sci. Eng. R, 36(5/6), 143-206. DOI: 10.1016/ S0927-796X(02)00004-9.

8. Morent, R., de Geyter, N., Verschuren, J., de Clerck, K., Kiekens, P., \& Leys, C. (2008). Non-thermal plasma treatment of textiles. Surf. Coat. Technol., 202(14), 3427-3449. DOI: 10.1016/j.surfcoat.2007.12.027.

9. Tendero, C., Tixier, C., Tristant, P., Desmaison, J., \& Leprince, P. (2006). Atmospheric pressure plasmas: A review. Spectrochim. Acta Part B, 61(1), 02-30. DOI: 10.1016/j.sab.2005.10.003.

10. Jasiński, M., Mizeraczyk, J., Zakrzewski, Z., Ohkubo, T., \& Chang, J. S. (2002). CFC-11 destruction by microwave plasma torch generated atmospheric-pressure nitrogen discharge. J. Phys. D-Appl. Phys., 35(18), 2274-2280. DOI: 10.1088/0022-3727/35/18/308.

11. Baeva, M., Gier, H., Pott, A., Uhlenbusch, J., Hoschele, J., \& Steinwandel, J. (2002). Pulsed microwave discharge at atmospheric pressure for NOx decomposition. Plasma Sources Sci. Technol., 11(1), 1-9. DOI: 10.1088/0963-0252/11/1/301.

12. Jasiński, M., Dors, M., \& Mizeraczyk, J. (2009). Destruction of freon HFC-134a using a nozzleless micro- wave plasma source. Plasma Chem. Plasma Process., 29(5), 363-372. DOI: 10.1007/s11090-009-9183-1.

13. Mizeraczyk, J., Jasiński, M., Nowakowska, H., \& Dors, M. (2012) Studies of atmospheric-pressure microwave plasmas used for gas processing. Nukleonika, 57(2), 241-247

14. Jasiński, M., Czylkowski, D., Hrycak, B., Dors, M., \& Mizeraczyk, J. (2013). Atmospheric pressure microwave plasma source for hydrogen production. Int. J. Hydrog. Energy, 38(26), 11473-11483. DOI: 10.1016/j.ijhydene.2013.05.105.

15. Mizeraczyk, J., Urashima, K., Jasiński, M., \& Dors, M. (2014). Hydrogen production from gaseous fuels by plasmas - A review. Int. J. Plasma Env. Sci. Technol., 8(2), 89-97.

16. Hrycak, B., Czylkowski, D., Miotk, R., Dors, M., Jasiński, M., \& Mizeraczyk, J. (2014). Application of atmospheric pressure microwave plasma source for hydrogen production from ethanol. Int. J. Hydrog. Energy, 39(26), 14184-14190. DOI: 10.1016/j. ijhydene.2014.02.160.

17. Hrycak, B., Czylkowski, D., Miotk, R., Dors, M., Jasinski, M., \& Mizeraczyk, J. (2015). Hydrogen production from ethanol in nitrogen microwave plasma at atmospheric pressure. Open Chem., 13(1), 317-324. DOI: $10.1515 /$ chem-2015-0039.

18. Czylkowski, D., Hrycak, B., Miotk, R., Jasiński, M., Dors, M., \& Mizeraczyk, J. (2015). Hydrogen production by conversion of ethanol using atmospheric pressure microwave plasmas. Int. J. Hydrog. Energy, 40(40), 14039-14044. DOI: 10.1016/j. ijhydene.2015.06.101.

19. Randolph, K. (2013). Hydrogen production. In Hydrogen and Fuel Cells - Annual Merit Review and Peer Evaluation Meeting, May 13-17, 2013, Arlington, Virginia, USA. U.S. Department of Energy (DOE).

20. Bromberg, L., Cohn, D. R., \& Rabinovich, A. (1997). Plasma reformer-fuel cell system for decentralized power applications. Int. J. Hydrog. Energy, 22(1), 83-94. DOI: 10.1016/0360-3199(95)00121-2.

21. Bromberg, L., Cohn, D. R., Rabinovich, A., Alexeev, N., Samokhin, A., Ramprasad, R., \& Tamhankar, S. (2000). System optimization and cost analysis of plasma catalytic reforming of natural gas. Int. J. Hydrog. Energy, 25(12), 1157-1161. DOI: 10.1016/ S0360-3199(00)00048-3.

22. Sekiguchi, H., \& Mori, Y. (2002). Steam plasma reforming using microwave discharge. Thin Solid Films, 435(1/2), 44-48. DOI: 10.1016/S00406090(03)00379-1.

23. Liu, K., Song, Ch., \& Subramani, V. (2010). Hydrogen and syngas production and purification technologies. Hoboken, New Jersey, USA: John Wiley \& Sons, Inc. 